\title{
Legal Relationship between Go-Jek Drivers and PT Go-Jek Indonesia in the E-Contract Partnership
}

\author{
Shandy Harsyahwardhana", Muhaimin ${ }^{* *}$, Eduardus Bayo Sili** \\ * Student of Magister Law Study Program, Postgraduate Program, Mataram University, Indonesia \\ ** Lecture of Law Faculty Mataram University, Indonesia
}

\begin{abstract}
This study aims to analyze the legal relationship of the e-contract partnership with Go-Jek drivers. The legalissue that is the focus of this study identifies and analyzes the legal relationship between Go-Jek drivers andPT Go-Jek Indonesia in a partnership agreement in the form of e-contract. This research method isnormative considering the existence of legal obscurity related to the partnership e-contract arrangement. Theresearch approach used is the Legislative Approach and the Conceptual Approach. With the pattern of equalcooperation in partnership, the reality is that the legal relationship between PT Go-Jek Indonesia and the Go-Jek driver has been inequality. Therefore, the Go-Jek driver as a legal subject becomes weak and needs legalprotection. Moreover, the partnership as outlined in the e-contract has not fully provided preventive andrepressive legal protection.
\end{abstract}

Keywords: legal relations, partnership, E-contract, Go-Jek

\section{Introduction}

Humans as social beings have many needs that must be fulfilled for the welfare of their lives. The human way to fulfill their needs, or how these efforts to achieve prosperity are then called economic activities. In supporting these needs, it is possible not to be fulfilled in one location. Therefore humans need transportation to transfer people and / or goods from one place to another by using a vehicle. ${ }^{1}$

In terms of use, the mode of transportation of people is classified into two (2) types, namely private vehicles and public vehicles. Private vehicles are types of vehicles that are only used by the owner of the vehicle, while public vehicles are vehicles that are provided for public use and are subject to fees. These public vehicles can be categorized into two types, namely rented vehicles (paratransit) and ordinary public transportation (transit). ${ }^{2}$

One type of transportation that is widely used in Indonesia is motorbikes. Based on data from the Indonesian Motorcycle Industry Association, Indonesia was the 3rd ranked in ASEAN related to motorcycle ownership, which is 1 person out of 44 people, or 6 million more Indonesians own a motorcycle. Motorbikes are included in the classification of private vehicles. But there is a unique phenomenon in Indonesia where many motorbikes are also found to function as public transport such as people and collecting agreed fees. This type of transportation is known as a motorcycle taxi.

The Big Indonesian Language Dictionary $(\mathrm{KBBI})$, motorcycle taxis are motorbikes (mines = leased vehicles) by renting who rent passengers. The services provided by this motorcycle taxi are delivery services to the requested location. With these characteristics, motorcycle taxis can also be referred to as part of the

\footnotetext{
${ }^{1}$ Abbas Salim, Manajemen Transportasi, PT Raja Grafindo Persada, Jakarta, 2000, p. 45

${ }^{2}$ Vuchic, Vukan R., Urban Passenger Transportation Modes, dalam Public Transportation, Second Edition, eds. Gray, George E dan Hoel, Lester A, Prentice Hall, Englewood Cliffs, New Jersey, 1992, p. 79
} 
paratransit mode. Paratransit mode that can be changed according to wishes of passengers (demand responsive). ${ }^{3}$

The presence of motorcycle taxis in the middle of Indonesian society has been transformed into public transportation to meet human needs. However, normatively or from the legal aspect, until now (in 2019) ojek is not recognized as public transportation. In Law No. 22 of 2009 concerning Road Traffic and Transportation (LLAJ Law), there is indeed no Article which expressly prohibits the operation of twowheeled public transportation such as motorcycle taxis. But because of Law No. 14 of 1992 and PP No. 41 of 1993 states that transportation of people by public vehicles is carried out using bus cars or passenger cars, so motorcycle taxis have not yet been recognized as public transportation modes.

In the midst of technological advances that are increasingly influencing people's behavior to seek convenience, one of them is the emergence of online motorcycle taxis. The birth of online motorcycle taxis is the result of information technology collaboration with public transportation equipment that aims to improve community service during the government's inability to present ideal transportation services. ${ }^{4}$ This online-based transportation system that has been used by urban communities has spread rapidly in various urban areas throughout Indonesia.

One of the big names of online-based transportation service providers in Indonesia is Go-Jek. Now, Go-Jek has operated in more than 50 cities in Indonesia. ${ }^{5}$ The community flocked to become the driver of the GoJek with a motorized vehicle, because it was believed that many of the drivers who joined became more prosperous after joining Go-Jek. ${ }^{6}$ As a new type of business, application provider companies such as PT GO-Jek Indonesia use partnership partnerships with Go-Jek drivers as outlined in e-contracts or electronic contracts.

Based on the ITE Law Article 1 number 17 and PP No. 82 of 2012, electronic contracts are parties' agreements made through the Electronic System. Meanwhile Edmon Makarim defines an online contract as an engagement or legal relationship that is carried out electronically by integrating networking from a computer-based information system with a communication system based on telecommunication based networks and services, which then facilitated by the existence of a global computer network Internet. ${ }^{7}$

However, the e-contract made by the business manager Go-Jek contains several Articles of partnership cooperation by default and there are several Articles in the terms of the agreement that are not beneficial for the work partners. In addition there is no room for partners to conduct reviews, objections and offers as part of the agreement agreement. ${ }^{8}$ This condition indicates the limitations of the ITE Law and its implementation rules in explaining holistically about this system of partnership contracts in electronic form.

Meanwhile, when reviewing other norms, namely the Civil Code, the Business Competition Law, the Consumer Protection Law, the UMKM Law and PP 17 of 2013 also faced several obstacles, where none of the norms clearly explained the e-contract. A number of these norms only explain the agreement in general, so the authors assess the existence of legal obscurity that regulates the e-contract between Go-Jek drivers and PT Go-Jek Indonesia. The vagueness of the norm has the potential to create a larger legal problem, especially related to legal protection against the Go-Jek driver as a partner. The problem is very interesting to study further, therefore the authors are interested in discussing and analyzing the legal relationship between the Go-Jek driver and PT Go-Jek Indonesia in an e-contract partnership agreement.

\section{Research Method}

This research is a normative legal research based on the consideration that the legal issue in this thesis is the legal obscurity of the arrangement of partnership contracts in the form of e-contracts. Normative legal research or library legal research methods are methods or methods used in legal research conducted by

\footnotetext{
${ }^{3}$ Ibid, p. 86

${ }^{4}$ Nurul Qamar dan Aan Aswari. Menyembuhkan Atau Semakin Melukai: Perkembangan Teknologi Transportasi Umum Jalan Raya. Jurnal Dinamika Hukum Vol 18, No 3 :2018, p. 1

${ }^{5}$ Go-Jek Indonesia, Satu Aplikasi Untuk semua kebutuhan, <https://www.go-jek.com/about/>, accessed on November 3,2017

${ }^{6}$ Ibid

${ }^{7}$ Edmon Makarim. Kompilasi Hukum Telematika, Rajawali Press, Jakarta, 2005. p. 253.

${ }^{8}$ Seta Wiharso. e-contract PT. Gojek Indonesia Perspektif Hukum Perjanjian Syariah. (Thesis of Master of Law in UIN Sunan Kalijaga, 2017), p. 2
} 
examining existing library materials. ${ }^{9}$ The first stage of normative legal research is research aimed at obtaining objective law (legal norms), namely by conducting research on legal issues. The second stage of normative legal research is research aimed at obtaining subjective laws (rights and obligations). ${ }^{10}$

In the study using 2 kinds of approaches namely the Legislative Approach and the Conceptual Approach. According to Ibrahim, the Statute Approach, namely "normative research, of course, must use legislation, because what will be examined is various legal rules that are the focus as well as the central theme in a study". 11 A normative study certainly must use a statutory approach, because what will be examined is a variety of legal rules that are the focus as well as the central theme of a study. This study will look at the legislation that underlies the partnership contract in the form of an e-contract. Then, the Conceptual Approach will also be used in this study to see the concepts of partnership contracts and econtracts contained in various literatures. This concept has many meanings.

In this study the author will use secondary data obtained through library studies equipped with field data. Primary legal materials in this thesis include:

1. Civil Code, Staatsblad 1847 Number 23 about Burgerlijk Wetboek Voor Indonesie (BW)

2. Law No. 5 of 1999 concerning Anti-Monopoly and Unfair Business Competition (State Gazette of the Republic of Indonesia of 1999 Number 33)

3. Law No. 8 of 1999 concerning Consumer Protection (State Gazette of the Republic of Indonesia of 1999 Number 42)

4. Law Number 11 Year 2008 concerning Information and Electronic Transactions (ITE) (State Gazette of the Republic of Indonesia Year 2008 Number 58)

5. Law Number 20 of 2008 concerning Micro, Small and Medium Enterprises (MSMEs) (State Gazette of the Republic of Indonesia of 2008 Number 93)

6. Law Number 22 of 2009 concerning Road Traffic and Transportation (State Gazette of the Republic of Indonesia of 2009 Number 96, Supplement to the State Gazette of the Republic of Indonesia Number 5025)

7. Government Regulation Number 82 of 2012 concerning Implementation of Systems and Electronic Transactions (State Gazette of the Republic of Indonesia of 2012 Number 189)

8. Government Regulation Number 17 of 2013 as Implementing Regulations for the Law on MSMEs (State Gazette of the Republic of Indonesia of 2013 Number 40)

Meanwhile secondary legal material is a textbook because the textbook contains the basic principles of law and classical views of scholars who have high qualifications, the literature related to the problems examined in this case is the legal relationship in the partnership agreement in the form of e-contract between Go-Jek driver and PT Go-Jek. The technique for collecting legal materials was carried out through library research. After that, the legal material processing is carried out systematically and then reasoning logically with descriptive analysis and drawing conclusions deductively towards vague of norms. The process of legal discovery by using the method of argumentation can be done by the method of interpretation, namely expanding the legislation, which is too narrow in scope, and applied to events regulated by law. Interpretation methods are often used in civil cases and are one of the methods of legal discovery in the event that the law is incomplete, so it is the filling or creation of a new law and not as a form of interpretation.

\section{Result And Discussion}

\subsection{E-contract of the Go-Jek Partnership in the Indonesian Legal System}

The Government of the Republic of Indonesia based on the 1945 Constitution (UUD) implemented a national development aimed at creating a just and prosperous society that was evenly distributed. In this national development, the Government of the Republic of Indonesia sees Micro, Small and Medium

\footnotetext{
${ }^{9}$ Soerjono Soekanto dan Sri Mamudji, Penelitian Hukum Normatif Suatu Tinjauan Singkat, $11^{\text {th }}$ Printing. (Jakarta : PT Raja Grafindo Persada, 2009), p. 13-14.

${ }^{10}$ Hardijan Rusli, "Metode Penelitian Hukum Normatif: Bagaimana?”, Law Review Fakultas Hukum Universitas Pelita Harapan, Volume V No. 3 Tahun 2006, p. 50.

${ }^{11}$ Johni Ibrahim, Teori \& Metodologi Penelitian Hukum Normatif, cetakan III (Bayumedia Publishing: Malang, 2007), p. 302
} 
Enterprises to play an important role in the development of popular economy so that it becomes one of the main pillars of the national economy. The formation of regulations in terms of business partnerships is one of the Government's efforts in developing strategic measures to support the development of Micro, Small and Medium Enterprises. In addition, it is also a preventive legal protection for parties who will hold partnership partnerships.

Based on Article 1 number (13) of Law Number 20 of 2008 concerning Micro, Small and Medium Enterprises, the Partnership is: "Cooperation in business relations, both directly and indirectly, on the principle of mutual need, trust, strengthen and benefit involving micro, small and medium business actors with large businesses. From the concept of partnership according to Law Number 20 Year 2008 Article 1 number 13, those involved as parties in partnership are Micro, Small and Medium Business Actors with Large Enterprises.

While it is seen from an etymological perspective, the partnership is adapted from the word partnership, and comes from the partner's root. The partner can be translated "partner, mate, ally, or campaigner". The meaning of partnership which is translated into partnership or partnership. ${ }^{12}$ With this description, the partnership can be interpreted as a form of partnership between two or more parties that forms a partnership of cooperation on the basis of agreement and a sense of mutual need in order to increase capacity and capability in a particular business field, or certain objectives, so that good results can be obtained .

Hafsah explained that the definition of partnership is a business strategy that is carried out by two or more parties within a certain period of time to gain profits together with the principle of mutual need and mutual nurturing. ${ }^{13}$ Because it is a business strategy, the success of partnerships is largely determined by the existence of compliance among partners who run business ethics. According to Anwar in Hafsah, economic development with a partnership pattern can be considered as the most profitable business (maximum social benefit), especially in terms of achieving long-term development goals. ${ }^{14}$ This is based on the realization of the ideals of a partnership pattern for the development of a populist economy where a mutual cooperation economic system is implemented between partners who are strong in terms of capital, markets, and technological capabilities with inexperienced small businesses. The aim is to increase business productivity and welfare on the basis of mutual interests.

Economically, partnerships are defined as: ${ }^{15}$

a. The essence of partnership lies in joint contributions, both in the form of labor (labor) and objects (property) or both for the purpose of economic activities. Control of activities is carried out jointly where the distribution of profit and loss distribution between the two partners. (Burns, 1996 in the Agribusiness Agency of the Ministry of Agriculture, 1998);

b. "Partnership or Alliance" is an association consisting of two people or businesses that share a company with the aim of making a profit. (Winardi, 1971 in the Agribusiness Department of Agriculture, 1998);

c. Partnership is an alliance of two or more people as joint owners who run a business looking for profit. (Spencer, 1977 in the Agribusiness Agency of the Ministry of Agriculture, 1998);

d. A partnership is a company with several money owners enjoying together the benefits of the company and each of them bears an unlimited liability for the company's debts. (McEachern, 1988 in the Agribusiness Agency of the Ministry of Agriculture, 1998).

But according to Law No. 20 of 2008 concerning Micro, Small and Medium Enterprises Article 11 stated that the objectives of the partnership program are:

a. Realizing a partnership between Micro, Small and Medium Enterprises;

b. Realizing a partnership between Micro, Small, Medium and Large Businesses;

c. Encouraging mutually beneficial relationships in the implementation of business transactions between Micro, Small and Medium Enterprises;

\footnotetext{
${ }_{12}^{12}$ Ambar Teguh Sulistiyani. Kemitraan dan Model-Model Pemberdayaan. Gaya Media. Yogyakarta. 2004 , p. 129

${ }^{13}$ Muhammad Jafar Hafsah, Kemitraan Usaha, Pustaka Sinar Harapan, Jakarta, 1999, p. 43

${ }^{14}$ Ibid, p. 12

${ }^{15}$ Mia Nur damayanti, Kajian Pelaksanaan Kemitraan Dalam Menigkatkan Pendapatan Antara Petani Semangka di Kabupaten Kebumen Jawa Tengah dengan CV. Bimandiri, IPB Press, Bogor, 2009, p. 18
} 
d. Encouraging mutually beneficial relationships in the implementation of business transactions between Micro, Small, Medium and Large Businesses;

e. Develop cooperation to increase the bargaining position of Micro, Small and Medium Enterprises;

f. Encourage the formation of market structures that guarantee the growth of fair business competition and protect consumers; and

g. Prevent market domination and market concentration by certain individuals or groups that harm Micro, Small and Medium Enterprises.

Based on the explanation of Article 11 above, the author assesses the intent and purpose of the core partnership is to run a business that is mutually beneficial between Large Businesses and MSMEs or "winwin solution partnership". The mutually beneficial context does not mean the parties in the partnership must have the same abilities and strengths, but what is more important is the existence of an equal bargaining position based on their respective roles. With the description and purpose of the partnership, the Ministry of Cooperatives and SMEs Deputy Human Resources Development Deputy, Rulli Nuryanto said the partnership was very important for two reasons. First, in an increasingly globalized era today no entity can be alone in an effort to survive and develop. Second, the era of the Industrial Revolution 4.0 was marked by the development of extraordinary information technology that affected various aspects of people's lives including consumer tastes. Thus in this era who is agile in anticipating technological developments that will survive and develop. ${ }^{16}$

Nowadays technology is able to provide new business opportunities in creative industries which are now called as start up. One of them is the Go-Jek application owned by PT Go-Jek Indonesia. The presence of Go-Jek in Indonesia is claimed as an effort to overcome the limitations of transportation modes and the lack of jobs. The development of PT Go-Jek in Indonesia due to the accuracy of Nadiem Makarim as the founder of Go-Jek saw the high number of workers in the informal sector, one of whom was a motorcycle taxi service provider. Referring to data released by the World Bank, in 2016 in Indonesia, of the total nonagricultural workers, 84.3 percent were informal sector workers. The character of informal sector workers is that their activities are not legal entities, so when GO-Jek came up with a ride-sharing business pattern by carrying out the concept of partnership, he received a quite positive response from the community.

In August 2016, there were 6.02 million workers in the informal sector in Indonesia. From that figure, GoJek absorbs 200 thousand workers, or 2.87 percent. A year later the number increased, where in August 2017 there were 5.84 million workers in the informal sector. Go-Jek absorbs 250 thousand people in the context of partners. PT Go-Jek as a technology-based company pays for partnership cooperation in the form of e-contracts or electronic contracts. E-contract based on Article 1 number 17 of Act Number 11 of 2008 concerning Information and Electronic Transactions is "agreement of the parties made through electronic or online systems". The agreement can be born through website e-mail, web sites, via electronic data interchange (EDI), and online methods and other technologies. ${ }^{17}$

E-contract was born without the meeting of parties directly, but transactional occurred through internet media. R. Setiawan also suggested several theories relating to the occurrence of agreements where the parties did not meet directly, namely: Speech Theory (Uitingstheorie), Delivery Theory (Verzendingstheorie), Knowledge Theory (Vernemingstheorie), and Receipt Theory (Ontvangsttheorie). ${ }^{18}$ Because this form of agreement is not specifically regulated in the Civil Code, the e-contract is an on-thespot contract. This agreement model is basically the same as the contract in general, but its actions are through electronic systems or using electronic media. Therefore, the making and implementation of the econtract other than subject to Law No. 11 of 2008 concerning ITE as a special legal rule (lex specialis), is also subject to the Civil Code of Book III concerning Engagement, especially Chapters I to Chapter IV and several Articles relevant in the KUH Trade as a general rule of law (lex generalis). ${ }^{19}$

16 Tribunnews.com, Hadapi Era Revolusi Industri 4.0, Pola Kemitraan Harus Dilakukan Agar UKM Maju, <http://www.tribunnews.com/bisnis/2018/11/01/hadapi-era-revolusi-industri-40-pola-kemitraan-harus-dilakukan-agar-ukmmaju.> accessed May 1, 2019

${ }^{17}$ Rosa Agustina, Kontrak Elektronik (E-Contract) Dalam Sistem Hukum Indonesia, (Gloria Juris Volume 8, JanuariApril,2008,Jakarta), p. 6

${ }^{18}$ R. Setiawan, Pokok-pokok Hukum Perikatan, (Bandung : Bina Cipta, 1999). p.58

${ }^{19}$ Ibid, p. 245 
In the context of the partnership agreement between GO-Jek Driver and PT GO-Jek, the partnership outlined in this kind of e-contract is new in Indonesian law. E-contract partnership is not only based on Law No. 11 of 2008 concerning ITE as a special legal rule (lex specialis), but also subject to partnership arrangements regulated in Law 20 of 2008 concerning MSMEs Article 34 jo PP 17 of 2013 Chapter III about the Partnership from Articles 10 to 35. Meanwhile, the elements in the e-contract at least contain at least about business activities; the rights and obligations of each party; form of development; time period; and settlement of disputes as stated in Law 20 of 2008 concerning MSMEs Article 34 Paragraph (1) jo PP 17 of 2013 Article 29 Paragraph (4).

Based on the results of the study and analysis of article per article in the e-contract the partnership between GO-Jek Driver and PT GO-Jek Indonesia, broadly fulfilled the terms of the partnership agreement stipulated in PP 17 of 2013 and Law 20 of 2008 concerning MSME Article 34. But still some aspects that have not been implemented by PT GO-Jek in making the agreement as mandated in Law 20 of 2008 concerning MSME Article 34 Paragraph (2) where the partnership agreement should be reported to the competent authorities in accordance with the provisions of the legislation. So far, the partnership agreement between GO-Jek Driver and PT GO-Jek Indonesia has never been reported to related parties in this case the Ministry of Transportation, the Ministry of UMKM, and the Ministry of Manpower. PT GO-Jek has so far only presented the partnership agreement electronically on its official website so that it can be accessed by everyone. Then PT GO-Jek as a Big Business actor in the agreement made GO-Jek Driver as a Partner on the one hand to be independent of all risks and losses due to negligence, but on the other hand made GOJek's dependence on the condition of Go Application and tariff determination policies by PT GO-Jek.

Although the Ministry of Transportation has issued Minister of Transportation Regulation No. 12 of 2019 concerning the Safety Protection of Motorcycle Users Used in the Interest of the Community, where one of its policies is the determination of tariffs based on zoning, the drivers are still very dependent on PT GOJek's policies regarding star rating or ratings from consumers often culminates in the provision of such activities as suspending or terminating partnership contracts. With this condition, the partnership agreement between GO-Jek Driver and PT GO-Jek Indonesia still has several weaknesses due to the limitations of several regulations governing partnerships, especially the absence of sanctions for Large Business actors such as GO-Jek who have not fully implemented the principles of partnership.

\subsection{Legal Relations in the E-contract of the Partnership between Go-Jek Drivers and PT Go-Jek Indonesia}

All relationships in society cannot be separated from the law. Legal relations are reflected in the inherent rights and obligations of each party bound to an agreement. ${ }^{20}$ According to Soeroso, in principle the law regulates the relationship between one person and another. All relationships in society cannot be separated from the law. Therefore legal relations are the relationship between two or more legal subjects. In this legal relationship the rights and obligations of one party are faced with the rights and obligations of the other. ${ }^{21}$ While according to Ishaq, legal relations are any relationships that occur between two legal subjects or more where rights and obligations on the one hand are faced with rights and obligations on the other. ${ }^{22}$

Based on this definition, basically the law has two aspects, namely the aspect of power/authority or right (bevoegheid) and the aspect of obligation (plicht). ${ }^{23}$ These rights and obligations arise as a result of an event regulated by law, as stated in Article 1457 of the Civil Code concerning engagement (verbintenis) arising from an agreement (overeenkomst). For example, in the partnership agreement between Go-Jek Driver to PT Go-Jek Indonesia, this agreement creates a partnership between Go-Jek and PT Go-Jek Indonesia drivers regulated by the UMKM Law and PP 17 of 2013. Where Go-Jek Drivers are required to follow all the conditions required by PT Go-Jek Indonesia to be entitled to use the Go-Jek Application, and PT Go-Jek Indonesia must provide a limited, non-exclusive, non-sublicensable, irrevocable and non-transferable license to Go-Jek Drivers to access and use the GO-JEK Application on Smartphone devices owned or controlled by the Partner solely related to the use of Partners on the GO-JEK Application and to access and use

\footnotetext{
${ }^{20}$ Sudikno Mertokusumo, Mengenal Hukum Suatu Pengantar, Penerbit Liberty, Yogyakarta, 2005, p. 41

${ }^{21}$ R. Soeroso, Pengantar Ilmu Hukum, Sinar Grafika, Jakarta, 2005, p. 269

${ }^{22}$ Ishaq, Dasar-dasar Ilmu Hukum, Jakarta, Sinar Grafika, 2008, p. 84

${ }^{23}$ Opcit, p. 269
} 
content/content, information and related material that can be provided through the GO-JEK Application , and solely for Partners as personal use. ${ }^{24}$

To realize a legal relationship, it must meet the requirements of having a legal basis and must cause legal events. ${ }^{25}$ In the partnership agreement between GO-Jek Driver and PT GO-Jek Indonesia, it was explained earlier that this agreement has a legal basis in the form of Law 20 of 2008 concerning MSMEs and PP 17 of 2013 which in some articles regulates partnerships between business actors. Then because the form of the partnership agreement is set forth in the e-contract, it must meet the provisions in the ITE Law and PP 82 of 2012. However, one more regulation that underlies this relationship is the Civil Code, specifically relating to the agreement.

However, in the Civil Code there is no specific article that explains or regulates partnerships, so the authors consider the partnership agreement to be included in a non-named agreement (Onbenoemd Overeenkomst). The birth of this agreement is based on the principle of freedom of contract which states that everyone is free to enter into agreements with anyone or autonomy. The arrangement of an agreement not named in the Civil Code is regulated in Article 1319 of the Civil Code, which defines all agreements, both those with special names and those not known by a particular name, subject to general regulations contained in this chapter and other chapters.

The existence of an agreement not named binding in Book III of the Civil Code adheres to an open system and the principle of freedom of contract, which is regulated in Article 1338 of the Civil Code. As explained in Article 1338 of the Civil Code, that: "All agreements made legally apply as laws for those who make them". The principle of freedom of contact here is not entirely free where it must not violate the legal requirements of an agreement contained in Article 1320 of the Civil Code. As for the legal conditions of an agreement as stipulated in Article 1320 of the Civil Code, namely: Agreed those who bind themselves; The ability to make an engagement; A certain thing; and a reason that is lawful. ${ }^{26}$

In connection with the above, in general an agreement is not bound to a certain form, the most important is the fulfillment of the legal terms of the agreement in accordance with Article 1320 of the Civil Code. Based on Article 1338 (1) of the Civil Code that all agreements made legally apply as laws for those who make them. This indicates the freedom of the parties to make an agreement. The agreement of a person to bind themselves is a decisive condition regarding the existence or absence of an agreement so that there is agreement from the parties regarding a certain thing that is agreed (and has fulfilled other requirements), then the parties will be bound by the agreement based on the principle of consensus. ${ }^{27}$

In the context of the legal relationship between legal subjects, namely GO-Jek Driver and PT GO-Jek Indonesia which was established in the partnership agreement, AKAB can be said to be the party that made and managed the account to be used by PT GO-Jek Indonesia and Partners to apply the cooperative relationship between PT GO-Jek Indonesia and Partners. Besides that, it also offers services to consumers which are then used by partners as well as in providing services and earning income. With this cooperative relationship it is in accordance with the legal relationship in the partnership agreement / civil company in Article 1618 of the Civil Code where it is said that the subject of civil partnership is two or more people who promise to include something (money / business / goods in this case is a GO Application -Jek) into the company to obtain mutual benefits.

On the other hand, there is limited, non-exclusive licensing rights that cannot be sublicensed, cannot be revoked, and cannot be transferred to GO-Jek drivers to access and use the GO-Jek Application in accordance with the power of attorney agreement. As stipulated in Article 1792 of the Civil Code, it is said that the subject of the power of attorney is the authorizer and the other person who receives (the proxy). In the viewpoint of the power of attorney agreement, the AKAB cannot be categorized in the agreement because it is not the authorizing party or the authorized person. However, in relation to the ITE Law, AKAB is a company that provides and administers the Go-Jek application system whose position can be based on

\footnotetext{
${ }^{24}$ Go Jek Partnership Cooperation Agreement Article 2 Cooperation Relations letter e

${ }^{25}$ Ibid, p. 271

${ }^{26}$ Salim H.S, Hukum Kontrak Teori Dan Teknik Penyusunan Kontrak, Jakarta: Sinar Grafika, 2017, $12^{\text {th }}$ Pprinting, p. $33-34$

${ }^{27}$ Salim HS dkk, Perancangan Kontrak \& Memorandum Of Understanding (MoU), Jakarta: Sinar Grafika, 2008, $4^{\text {th }}$ Printing, p. $25-26$
} 
the ITE Law Article 1 number 6, namely the organizer of an electronic system that can be a Business Entity/person/government.

The legal subject in this partnership agreement that has a relationship as a proxy is PT GO-Jek Indonesia. In the partnership agreement, it was explained that PT GO-Jek Indonesia or GO-Jek was the company that cooperated with partners by utilizing the application provided by the AKAB. Whereas from the point of view of a civil partnership agreement PT Go-Jek Indonesia can be said to be an ally that provides money in which PT Go-Jek Indonesia funds the AKAB to develop applications and Gi also facilitates partners to use the application for use in offering services to consumers.

Furthermore, GO-Jek driver as a partner is an individual person who cooperates with PT GO-Jek Indonesia and is subject to the terms and conditions set out in the partnership agreement to carry out passenger / goods transportation services using his own private vehicle. The driver position of GO-Jek in a civil partnership can be categorized in Article 1618 and 1619 of the Civil Code, where GO-Jek drivers are those who enter businesses to obtain consumers. Whereas in the power of attorney agreement in Article 1792 KUH Perdata, GO-Jek driver is the party authorized by PT GO-Jek Indonesia to use the Go-Jek Application to run a transportation or freight service business that is bound by the provisions stipulated by PT GO-Jek Indonesia and the AKAB.

If you see the partnership agreement between GO-Jek Driver and PT GO-Jek Indonesia as explained and drawn before, it is quite in accordance with the norms and doctrines of the treaty law that apply in Indonesia. Where the legal relationship of the partnership between GO-Jek Driver and PT GO-Jek Indonesia is in accordance with the norms and doctrines that exist in civil partnership agreements, authorization and also the ITE Law. In other words, the partnership relationship between GO-Jek Driver and PT GO-Jek Indonesia from the aspects of legal subjects in treaty law as contained in the Civil Code is the power of attorney and recipient of power in accordance with Article 1792 of the Civil Code.

Related to the legal object in the e-contract agreement of the partnership between GO-Jek Driver and PT GO-Jek Indonesia, in general in Article 1320 the Civil Code is governed by "certain things" and "halal causes". But specifically the object of this agreement is very dependent on the type of agreement itself. As previously discussed, the partnership agreement between GO-Jek Driver and PT GO-Jek Indonesia is a type of civil partnership agreement, power of attorney agreement and electronic agreement in accordance with ITE Law. Where these three types of agreements have different characters related to legal objects.

In a civil partnership agreement, which is the object of the agreement, it is regulated in Article 1619 of the Civil Code where each member is required to enter money/goods/business. So the object in a civil partnership can be in the form of money/goods/business from allies or members. Whereas in the Power of Attorney Agreement, which is the object of agreement is the power itself which is regulated in Article 1793 of the Civil Code, where power can be given and accepted by a general deed, with a letter under the hand, even with a letter or verbally. Then from the norms in the ITE Law, it also explains that the object of electronic agreement is a contract made in the form of an electronic system written in Article 1 number 17.

In the partnership agreement between GO-Jek Driver and PT GO-Jek Indonesia, it was explained that the legal object agreed upon was in the form of an application provided by the AKAB. Based on the perspective of the civil partnership agreement according to Article 1619 of the Civil Code where the object of a civil partnership can be goods, money, business. Here the Go-Jek application can be classified as an item. Meanwhile, if referring to the power of attorney agreement pursuant to article 1792 of the Civil Code, the object in the agreement relationship between GO-Jek Driver and PT GO-Jek Indonesia is in the form of the GO-Jek Indonesia driver to which GO-Jek driver The power of attorney is in the form of giving account access to partners to use the GoJek Application where partners cannot make their own provisions in performing services, but only can do services that have been determined by PT GO-Jek Indonesia and AKAB along with the payment rates in the application Go-Jek. This is in accordance with Article 1793 of the Civil Code where the power of attorney can be granted and accepted by a general deed, with a letter under the hand, even with a letter or verbally.

In the norms of civil partnership agreements, it has been stipulated that basic rights and obligations must be rights and obligations arising from the object of the agreement which in Article 1619 of the Civil Code is goods, money or business. In the norms of the power of attorney the agreement has also been explicitly regulated in Article 1797 of the Civil Code which says that the power of attorney may not do things that 
exceed the power of attorney granted. In the ITE norm, it has also been explained in detail about the obligations of business actors who offer businesses through electronic systems in Article 9 of the ITE Law, and also the obligations of providers of electronic systems in Article 15 to 16 of the ITE Law. Whereas in the Go-Jek partnership agreement data, the obligations of each party have also been written in the CHAPTER with the agreement of "Collaborative Relations" between the AKAB, GI and partners, which of course has the right of one party to other party.

The obligation on the AKAB is in accordance with the obligations of civil partnership members to include something in the form of goods/money/business. In this case the AKAB has provided goods in the form of an application, which is in accordance with Article 1619 of the Civil Code. In addition, the obligation of this ACCAB is in accordance with Law No. 19 of 2016 concerning ITE in Articles 15 and 16 which regulates the standardization of the implementation of electronic systems. The obligation to PT GO-Jek Indonesia is in accordance with the authorizing obligations where PT GO-Jek Indonesia gives the power partner to use the Go-Jek application after the partners comply with all regulations compiled by PT GO-Jek Indonesia. This is in accordance with 1807 of the Civil Code which says "The giver of power must fulfill the commitments made by the recipient of the power according to the power he has given him". He is not bound by what is done outside of that power, unless he has agreed to it explicitly or secretly. The obligation of partners as recipients of power of attorney is in accordance with Article 1797 of the Civil Code where partners only carry out services offered by PT GO-Jek Indonesia to consumers in the application. Whereas the partner's obligation as a civil partnership is also in accordance with Article 1619 of the Civil Code where partners contribute in the form of an effort to offer services that later benefit from the service will be entered into an account and shared with the three parties (PT GO-Jek Indonesia, AKAB) according to the provisions PT GO-Jek Indonesia.

Based on the explanation above, it can be concluded that the partnership agreement between GO-Jek Driver and PT GO-Jek Indonesia contained in the e-contract is included in the Obligatory Agreement group. Where the Obligatory Agreement is an agreement that requires someone to submit or pay for something. But specifically, this partnership agreement is included in the type of the Nameless Agreement (Onbenoemd Overeenkomst). Non-Named Agreement (Onbenoemd) are agreements that are not regulated in the Civil Code but are found in the community. Although it is not specifically regulated in the Civil Code, this agreement was born based on the principle of freedom of contract and entered into an agreement. Therefore, the partnership agreement is also subject to the terms of the legal agreement under the Civil Code. On the other hand, judging from the legal relationship that occurs between the parties in the partnership agreement there are elements of a civil partnership agreement and authorization, so that it can also be referred to as a mixed agreement. Mixed Agreement is an agreement that contains various elements of the agreement. Although it consists of several elements of the agreement, the legal consequences of the parties to the partnership agreement are subject to the contents of the agreement that has been agreed upon as the principle of consensualism in Article 1320 of the Civil Code.

Of the types of mixed agreements, it can be further seen about the types of legal relations of the parties to the agreement. If viewed from the point of view of the position of legal subjects who conduct legal relations, the legal relationship between GO-Jek drivers and PT GO-Jek Indonesia is a different degree of relationship (nacheinander). Different degrees are said because in the partnership agreement between the two parties determine different rights and obligations. Then the degree or status between the two parties is not equivalent if viewed from the classification of business actors as stipulated in the Law on MSMEs. PT GOJek Indonesia as a Big Business Actor while the GO-Jek Driver is a micro business. This unequal relationship made GO-Jek drivers unable to dodge or file complaints when there was a policy change by PT GO-Jek, such as the case of changes in tariffs to the determination of bonuses. The drivers were only faced with the choice not to continue the contract, resulting in a dependency relationship from GO-Jek's driver to PT GO-Jek as the owner of GO-Jek Application. This condition when viewed from the nature of legal relations shows the unequal nature of Legal Relations. Whereas in writing the e-contract shows the nature of reciprocity because there are rights and obligations of the parties. The confusion in this agreement makes GO-Jek's driver's position as a legal subject weak and requires legal protection. 


\section{Conclusion}

Based on the results of the study it can be concluded that the e-contract of the partnership between Go-Jek Drivers and PT Go-Jek Indonesia has a civil partnership and power of attorney relationship, so it can also be referred to as a mixed agreement. From the point of view of the position of legal subjects who carry out legal relations, the legal relationship between Go-Jek drivers and PT Go-Jek Indonesia is a different degree of relations (nacheinander). This condition creates a dependency relationship between Go-Jek drivers to PT Go-Jek as the owner of the Go-Jek Application. Whereas in writing the e-contract shows the nature of reciprocity because there are rights and obligations of the parties. The confusion in the e-contract of the partnership has made GO-Jek's driver position as a legal subject weak and requires legal protection.

\section{References}

\section{Books}

[1] H.S, Salim dkk. 2008. Perancangan Kontrak \& Memorandum of Understanding (MoU). $4^{\text {th }}$ Printing. Sinar Grafika, Jakarta. 2017. Hukum Kontrak Teori Dan Teknik Penyusunan Kontrak. $12^{\text {th }}$ Printing. Sinar Grafika, Jakarta

[3] Hafsah, Muhammad Jafar. 1999. Kemitraan Usaha. Pustaka Sinar Harapan, Jakarta.

[4] Ibrahim, Johni. 2007. Teori \& Metodologi Penelitian Hukum Normatif. $3^{\text {th }}$ Printing. Bayumedia Publishing, Malang.

[5] Ishaq. 2008. Dasar-dasar Ilmu Hukum. Sinar Grafika, Jakarta.

[6] Makarim, Edmon. 2005. Kompilasi Hukum Telematika. Jakarta: Rajawali Press .

[7] Mertokusumo, Sudikno. 2009. Penemuan Hukum. Citra Aditya Bakti, Bandung.

[8] Salim, Abbas. 2000. Manajemen Transportasi. PT Raja Grafindo Persada, Jakarta.

[9] Setiawan, R. 1999. Pokok-pokok Hukum Perikatan. Bandung : Bina Cipta.

[10] Soekanto, Soerjono \& Sri Mamudji. 2009. Penelitian Hukum Normatif Suatu Tinjauan Singkat. $11^{\text {th }}$ Printing. PT Raja Grafindo Persada, Jakarta.

[11] Soeroso, R. 2005. Pengantar Ilmu Hukum, Sinar Grafika, Jakarta.

[12] Sulistiyani, Ambar Teguh. 2004. Kemitraan dan Model-Model Pemberdayaan. Gaya Media. Yogyakarta.

[13] Vuchic, Vukan R. 1992. Urban Passenger Transportation Modes, in Public Transportation, Second Edition, eds. Gray, George E \& Hoel, Lester A, Prentice Hall, Englewood Cliffs, New Jersey.

[14] Agustina, Rosa Kontrak Elektronik (E-Contract) Dalam Sistem Hukum Indonesia, Gloria Juris Volume 8, January-April 2008, Jakarta,

[15] Damayanti, Mia Nur. Kajian Pelaksanaan Kemitraan Dalam Menigkatkan Pendapatan Antara Petani Semangka di Kabupaten Kebumen Jawa Tengah dengan CV. Bimandiri, IPB Press, Bogor, 2009.

[16] Qamar, Nurul dan Aan Aswari. Menyembuhkan Atau Semakin Melukai: Perkembangan Teknologi Transportasi Umum Jalan Raya. Jurnal Dinamika Hukum Vol 18, No 3, 2018

[17] Rusli, Hardijan. Metode Penelitian Hukum Normatif: Bagaimana? Law Review Fakultas Hukum Universitas Pelita Harapan, Volume V No. 3, 2006.

[18] Wiharso, Seta. e-contract PT. Go-Jek Indonesia Perspektif Hukum Perjanjian Syariah. Thesis UIN Sunan Kalijaga Yogyakarta, 2017.

\section{Regulations}

[1] Civil Code, Staatsblad 1847 Number 23 about Burgerlijk Wetboek Voor Indonesie (BW)

[2] Law No. 5 of 1999 concerning Anti Monopoly and Unfair Business Competition (State Gazette of the Republic of Indonesia of 1999 Number 33)

[3] Law No. 8 of 1999 concerning Consumer Protection (State Gazette of the Republic of Indonesia of 1999 Number 42) 
[4] Law Number 22 Year 2009 concerning Road Traffic and Transportation (State Gazette of the Republic of Indonesia of 2009 Number 96, Supplement to State Gazette of the Republic of Indonesia Number 5025)

[5] Law Number 11 Year 2008 concerning Information and Electronic Transactions (ITE) (State Gazette of the Republic of Indonesia Year 2008 Number 58)

[6] Law Number 20 of 2008 concerning Micro, Small and Medium Enterprises (MSMEs) (State Gazette of the Republic of Indonesia Year 2008 Number 93)

[7] Government Regulation Number 17 of 2013 as Implementing Regulations for the Law on MSMEs (State Gazette of the Republic of Indonesia of 2013 Number 40)

[8] Government Regulation Number 82 of 2012 concerning Implementation of Systems and Electronic Transactions (State Gazette of the Republic of Indonesia of 2012 Number 189)

[9] GO-Jek Partnership Agreement 